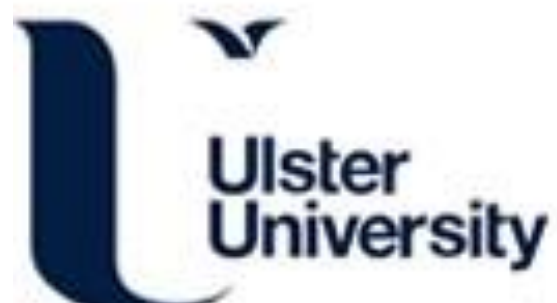

\section{The link between information processing capability and competitive advantage mediated through decision-making effectiveness}

Cao, G., Duan, Y., \& Cadden, T. (2019). The link between information processing capability and competitive advantage mediated through decision-making effectiveness. International Journal of Information Management, 44, 121-131. https://doi.org/10.1016/j.jinfomgt.2018.10.003

Link to publication record in Ulster University Research Portal

\section{Published in:}

International Journal of Information Management

Publication Status:

Published (in print/issue): 28/02/2019

DOI:

10.1016/j.ijinfomgt.2018.10.003

\section{Document Version}

Author Accepted version

\section{General rights}

Copyright for the publications made accessible via Ulster University's Research Portal is retained by the author(s) and / or other copyright owners and it is a condition of accessing these publications that users recognise and abide by the legal requirements associated with these rights.

\section{Take down policy}

The Research Portal is Ulster University's institutional repository that provides access to Ulster's research outputs. Every effort has been made to ensure that content in the Research Portal does not infringe any person's rights, or applicable UK laws. If you discover content in the Research Portal that you believe breaches copyright or violates any law, please contact pure-support@ulster.ac.uk. 


\title{
The link between information processing capability and competitive advantage mediated through decision-making effectiveness
}

\author{
Guangming Cao ${ }^{\mathrm{a}, *}$, Yanqing Duan ${ }^{\mathrm{b}}$, Trevor Cadden $^{\mathrm{c}}$ \\ a Department of Business Systems and Operations, University of Bedfordshire Business School, Park Square, Luton LU1 3JU, UK \\ ${ }^{\mathrm{b}}$ University of Bedfordshire Business School, Park Square, Luton LU1 3JU, UK \\ ' Ulster Business School, University of Ulster, Newtownabbey, BT37 OQB, UK
}

\section{A R T I C L E I N F O}

\section{Keywords:}

Information processing capability

Decision-making effectiveness

Competitive advantage

Resource-based view

Business analytics

Mediation

\begin{abstract}
A B S T R A C T
While research underpinned by the resource-based view (RBV) appears to suggest that IT-enabled capabilities are positively linked to competitive advantage, such a link is often seen as a black box as the processes through which competitive advantage can be gained appears unclear. In particular, research appears to suggest that information processing capability is linked to decision-making effectiveness and competitive advantage; however, little research appears to examine the interrelationship among them. This study, drawing on the RBV, develops a mediation model to examine the link between competitive advantage and the key tenets of value, rarity, inimitability and non-substitutability of information processing capability in the context of business analytics; and whether this link is mediated through decision-making effectiveness. Based on data collected from 633 UK companies, this study shows that there is a positive link between the value, rarity and inimitability characteristics of information processing capability and competitive advantage, which is partially mediated by decision-making effectiveness. The findings contribute to the theoretical development of the RBV by developing a mediation model that looks inside the black box. They also contribute to managers' knowledge and understanding of the mechanism through which the strategic value of information processing capability can be maximized.
\end{abstract}

\section{Introduction}

Many studies underpinned by the resource-based view (RBV) (Barney, 1991; Wernerfelt, 1984) have examined and supported the link between IT-enabled organizational capabilities and competitive advantage (e.g. Barua, Konana, Whinston, \& Fang, 2004; Peppard \& Ward, 2004; Fink \& Neumann, 2009). For example, it is shown that IT enabled flexibility is positively related to competitive advantage based on data collected from 293 Israel IT managers (Fink \& Neumann, 2009). While earlier studies based on the RBV have provided a useful grounding for understanding the important role of IT-enabled capabilities in improving competitive advantage, understanding the mechanisms through which IT-enabled capabilities contribute to competitive advantage has been a complex issue (Farbey, Targett, \& Land, 1994; Melville, Kraemer, \& Gurbaxani, 2004) and still remains a challenging task (Cao, Duan, Cadden, \& Minocha, 2016; Kim, Shin, Kim, \& Lee, 2011; Kohli \& Grover, 2008). Moreover, examining the direct link between resources/capabilities and competitive advantage has been criticized for lacking face validity (Ketchen, Hult, \& Slater, 2007), creating a black box issue as there is minimal theory to support such a direct link (Kraaijenbrink, Spender, \& Groen, 2010; Priem \& Butler, 2001; Sirmon, Hitt, \& Ireland, 2007), and/or neglecting the socially embedded qualities of organizational capabilities (Scarbrough, 1998). It appears that some of the idiosyncrasies and nuances of IT-enabled organizational capabilities and their links to competitive advantage are yet to be deconstructed. Arguably, two significant research gaps remain in the literature. First, except for a few (e.g. Autio, Sapienza, \& Almeida, 2000; Markman, Espina, \& Phan, 2004; Nevo \& Wade, 2011), most empirical studies that examine the link between a firm's resources/ capabilities and competitive advantage based on the RBV claim that the specific resource/capability is valuable, rare, inimitable, and non-substitutable (VRIN); and then the amount of that resource/capability is correlated with competitive advantage directly without operationalizing and testing part or all of the VRIN conditions to explain why competitive advantage can be obtained (Markman et al., 2004; Newbert, 2007). Second, although conceptual research suggests that factors may exist to mediate the link between IT-related capabilities and competitive advantage (e.g. Sambamurthy, Bharadwaj, \& Grover, 2003;

\footnotetext{
* Corresponding author.

E-mail address: guangming.cao@beds.ac.uk (G. Cao).
} 
Melville et al., 2004; Kohli \& Grover, 2008), only a limited body of empirical evidence exists to examine relevant mediators and their impacts (e.g. Tippins \& Sohi, 2003; Ravichandran, Lertwongsatien, \& Lertwongsatien, 2005; Pavlou \& El Sawy, 2006). In order to better understand the link between IT-related capabilities and competitive advantage, more research is required (Sirmon et al., 2007).

This article attempts to address the above research gaps by examining the mechanism through which competitive advantage is gained from information processing capability that is one type of the ITrelated capabilities (Premkumar, Ramamurthy, \& Saunders, 2005; Wang, Tai, \& Grover, 2013): the ability to process data/information and utilize information (Cao, Duan, \& Li, 2015; Tushman \& Nadler, 1978). This capability is closely associated with business analytics (Cao et al., 2015; Chen, Preston, \& Swink, 2015) that refers to the processes and techniques of data analysis for the generation of knowledge and intelligence. While research suggests that information processing capability is positively associated with decision-making effectiveness (Kiron, Prentice, \& Ferguson, 2014; Cao et al., 2015; Chen et al., 2015; Ransbotham, Kiron, \& Prentice, 2016) and competitive advantage (Collins \& Clark, 2003; Wang, 2003; Premkumar et al., 2005; Wang et al., 2013; Chen et al., 2015), no research appears to have conceptualized and tested the interrelationship between information processing capability, decision-making effectiveness, and competitive advantage. Thus, this study focuses on the following two main research questions: (1) Are the VRIN conditions of information processing capability linked to competitive advantage? (2) Whether and to what extent does decision-making effectiveness mediate the link between information processing capability's VRIN conditions and competitive advantage?

Drawing on the RBV and building on studies that have examined the link between IT-related capabilities and competitive advantage, this article attempts to look inside the black box by conceptualizing and testing a mediation relationship between information processing capability's VRIN conditions, decision-making effectiveness, and competitive advantage. Partial least squares structural equation modeling (PLSSEM) is used to test the research model, based on 633 responses collected from an online questionnaire survey conducted with UK businesses.

Hence, this article contributes to the RBV by looking inside the black box and providing an explanation of, and new insight into, the processes through which information processing capability may provide competitive advantage. This study also advances our understanding of the interrelationship between IT-related capabilities, decision-making effectiveness, and competitive advantage.

The remainder of this paper proceeds as follows. The next section presents the mediation model and the associated hypotheses. The subsequent section describes the instrument development and the data collection processes and reports on the empirical results. The final section discusses the results and implications.

\section{Theoretical background}

\subsection{Key concepts defined}

Before developing a mediation model, three key concepts to be used in this research are clarified, including information processing capability, decision-making effectiveness, and competitive advantage. Information processing capability is initially used by Galbraith (1974) and then adopted by Tushman and Nadler (1978) to refer to "the gathering, interpreting, and synthesis of information in the context of organizational decision making" (p.614). Largely consistent with this, similar definitions have been used in different research contexts. For example, information capabilities include information gathering, processing, and distribution in the context of strategic human resource management (Collins \& Clark, 2003) while information processing capability is defined as "the level of IT support for various activities" in an inter- organizational supply chain context (Premkumar et al., 2005, p.266). Recently, information processing capability is defined as the capacity to capture, integrate, and analyze data/information, and utilize information and insights in the context of organizational decision-making (Cao et al., 2015). Consistent with studies on business analytics (e.g. Davenport, 2006; Lavalle, Lesser, Shockley, Hopkins, \& Kruschwitz, 2011; Barton \& Court, 2012), Cao et al. (2015) show that in order for an organization to develop information processing capability from business analytics, it needs to create a data-driven environment that is characterized by developing explicit strategy and policy and designing its structure and processes to enable analytic activities. Building on Cao et al. (2015), this research will further examine how competitive advantage can be gained from information processing capability enabled by the use of business analytics.

The second key concept used in this research is decision-making effectiveness, which refers to the extent to which a decision either results in desired outcomes (Dillon \& Tinsley, 2008; Eisenhardt \& Zbaracki, 1992; Hammedi, Riel, \& Sasovova, 2013) or responds to rapid changes (Lessard \& Zaheer, 1996) in the literature on strategic decisionmaking. This concept has been measured by various indictors in a number of different research areas, such as innovation success (van Riel, Semeijn, Hammedi, \& Henseler, 2011), decision success as the expected proportion of correct choices (Newell, Rakow, Weston, \& Shanks, 2004), decision quality as the degree to which a judgment conforms to normative benchmarks (DeCarlo, Roy, \& Barone, 2015), or organizational performance (Elbanna \& Child, 2007; Goll \& Rasheed, 1997). Likewise, research on business analytics has indicated that effective decision-making will help a company understand customers, serve them better, and increase customer loyalty (e.g. Davenport, 2006; Kiron \& Shockley, 2011; Lavalle et al., 2011; Davenport, 2013a); make decisions faster and timely than ever before (Davenport, Harris, De Long, \& Jacobson, 2001; Kiron \& Shockley, 2011); and "empower employees to act confidently and decisively in a fast-paced marketplace" (Kiron \& Shockley, 2011, p.12) or "act more quickly" (Kiron, Prentice, \& Ferguson, 2012, p.11). Building on the literature on strategic decisionmaking and business analytics, this article follows Cao et al. (2015) to understand decision-making effectiveness as the extent to which a strategic decision enables a company to be more effective at understanding customers, making real-time decisions, and responding more quickly to change.

The third key concept used in this article is competitive advantage, which means a company has attained superior performance relative to other competitors (Lazzarini, 2015; Schilke, 2014) by for example achieving cost leadership or being differentiated in what it offers (Porter, 1985), or having developed a strategy that is value-creating and not being implemented by competitors (Barney, 1991). From the RBV, resources/capabilities meeting the VRIN conditions lead to sustainable competitive advantage (Barney, 1991; Kraaijenbrink et al., 2010). According to Nevo and Wade (2010), value refers to the ability of a firm's resource to support strategies such as exploiting market opportunities; rarity refers to what extent a firm's resource is unavailable to competitors; inimitability relates to the costs and difficulties of duplicating the resource; and non-substitutability refers to the nonexistence of equivalent resources.

In line with the above, this study understands information processing capability as "a special type of resource, specifically an organizationally embedded non-transferable firm-specific resource" (Makadok, 2001, p.389), thereby to examine its impact on competitive advantage. Subsequently, relevant research will be discussed to develop a mediation model and the associated hypotheses, thereby to explain the interrelationship between information processing capabilities, decisionmaking effectiveness, and competitive advantage.

\subsection{Theoretical development}

With respect to the first research question about the link between 
information processing capability's VRIN conditions and competitive advantage, no research has been conducted to examine this link by operationalizing and testing the VRIN conditions. However, IT related research has suggested that information processing capability is associated with firm performance (Wang, 2003). In the context of supply chain management, it is demonstrated that information processing capability has a significant effect on supply chain company performances (Premkumar et al., 2005; Wang et al., 2013) and asset productivity and business growth (Chen et al., 2015). Recently, practiceoriented research suggests that information processing capability based on business analytics is likely to help companies to gain competitive advantage (e.g. Davenport et al., 2001; Kiron \& Shockley, 2011; Kiron et al., 2012), although this is yet to be verified through hypothesis testing.

Nevertheless, a direct link between IT-related capability and competitive advantage seems highly plausible and has been supported by a number of studies underpinned by the RBV in a variety of research areas (e.g. Bharadwaj, 2000; Barua et al., 2004; Mithas, Tafti, Bardhan, \& Mein Goh, 2012). For example, Collins and Clark (2003) show that a company's information capability affects its competitive advantage in American high technology companies; Sook-Ling, Ismail, and Yee-Yen, (2015) demonstrate that information processing capability is positively related to competitive advantage while Lim, Stratopoulos, and Wirjanto, (2012), based on a sample of large US firms, show that senior IT executives help develop superior IT capability, which in turn has a positive impact on competitive advantage. Therefore, it is believable to assume a direct link between information processing capability and competitive advantage.

However, only examining this kind of direct link is insufficient (e.g. Ketchen et al., 2007; Newbert, 2007; MacKinnon, 2008) as the likely processes through which competitive advantage can be gained remains in a black box (Kraaijenbrink et al., 2010; Priem \& Butler, 2001; Sirmon et al., 2007). Arguably, one way to better understand the link between information processing capability and competitive advantage is to examine whether information processing capability meets the VRIN conditions to become a source of competitive advantage.

In most empirical studies underpinned by the RBV to examine the link between a company's resources/capabilities and competitive advantage, specific resource/capability is often claimed to meet the VRIN conditions and then the amount of that resource/capability is directly correlated with competitive advantage; the VRIN conditions are rarely operationalized and tested, except for a few studies (Autio et al., 2000; Markman et al., 2004; Nevo \& Wade, 2011). While Autio et al. (2000) empirically examine the relationship between a firm's technology imitability and its growth in international sales, Markman et al. (2004) test whether inimitable and non-substitutable patents are positively related superior performance in the context of pharmaceutical industry. Nevo and Wade (2011), instead, have tested all VRIN conditions and demonstrate that IT-enabled resources are positively related to the value, rarity, and inimitability, which in turn have a positive and direct effect on strategic benefits. However, they show that the path leading from non-substitutability to strategic benefits is not statistically significant.

Besides, there seems to be conceptual issues with the concept of non-substitutability. Nevo and Wade (2010) argue that there is no logical or theoretical reason to hypothesize that IT-related resources are non-substitutable. Newbert (2007), based on a literature review of empirical studies underpinned by the RBV, suggests that non-substitutability is merely a form of inimitability, thus it is rarely examined empirically.

Specifically focusing on information processing capability being examined in the context of business analytics, this article argues that it meets the VRIN conditions. Information processing capability tends to be valuable. Research suggests that information processing capability is for example the combined result of business analytics and other organizational factors such as a data-driven environment that is characterized by developing explicit strategy and policy and designing its structure and processes to enable analytic activities (Cao et al., 2015). Similarly, a number of studies suggest that in order for a company to develop its information processing capability from using business analytics, it must develop analytically driven strategy (Davenport \& Harris, 2007), design relevant business processes (Barton \& Court, 2012) and organizational structure (Acito \& Khatri, 2014) to enable analytics activities. As a result, information processing capability is seen to be the combined result of business analytics and a data-driven environment (Cao et al., 2015) and the joint use of assets or combining resources in a company is value enhancing (Teece, 2007) and synergistic (Eisenhardt \& Martin, 2000). Consequently, the value of information processing capability can be exemplified by providing datadriven insights, improved decision-making (Cao et al., 2015; Chen et al., 2015), innovation and competitive advantage (e.g. Lavalle et al., 2011; Davenport, 2013b; Kiron et al., 2014).

Furthermore, probably because the joint use of assets is value enhancing and synergistic, information processing capability is also likely to be rare. Research on business analytics suggests that many companies are still struggling to figure out how to use business analytics or how to achieve a worthwhile return from its investment in business analytics (Barton \& Court, 2012; Kiron et al., 2012). For example, there is indication that manufacturing among all sectors has been slow in incorporating business analytics (Dutta \& Bose, 2015). A more recent survey (Ransbotham et al., 2016) indicates that while companies' access to useful data has continued to increase over the years, processing data, disseminating and using data insights remain one of the biggest challenges; consequently, many companies still find that it is difficult to apply analytical insights to guide business strategy and to gain competitive advantage. This difficulty in creating value from developing and capitalizing information processing capability is probably because many firms do not have the ability to use assets such as business analytics and a data-driven environment jointly. Nolan and McFarlan (2005) assert that most firms even "remain largely in the dark when it comes to IT spending and strategy" (p. 96); then arguably they would be most unlikely to have managed the complex relation between business analytics and a data-driven environment to develop information processing capability. Similarly, Lim, Stratopoulos, and Wirjanto, (2011) suggest that only a subset of firms has been actively developing IT capabilities and they are more likely to repeat this than firms lacking such experience. Therefore, it can be argued that information processing capability is extremely likely to be rare.

Information processing capability is also likely to be inimitable, since it is based on buyer and suppliers relation in a supply chain context (Wang et al., 2013), is the combined result of business analytics and firm innate factors such as a data-driven environment (Cao et al., 2015), is associated with analytically driven strategy (Davenport \& Harris, 2007), relevant business processes (Barton \& Court, 2012), and/ or organizational structure (Acito \& Khatri, 2014). Thus, information processing capability is socially complex and difficult to be duplicated (e.g. Miller, 2003; Ray, Barney, \& Muhanna, 2004; Teece, 2007) since unique capability created from the interdependence among various organizational factors is impossible to be copied (Miller, 1996).

On the whole, this research sees that information processing capability is complex, causal-ambiguous, and difficult to be imitated; therefore, it is highly likely to meet the VRIN conditions and to become a source of competitive advantage. As a result, it is reasonable to believe that there is a link between information processing capability and competitive advantage. However, rather than to assume a direct link between information processing capability and competitive advantage, which is an approach that has been criticized as problematic and being a black box (Kraaijenbrink et al., 2010; MacKinnon, 2008; Newbert, 2007; Priem \& Butler, 2001), this research believes that it is more pertinent to postulate that there is a direct link between information processing capability's value, rarity, inimitability and non-substitutability and competitive advantage. Thus, the following hypothesis is 


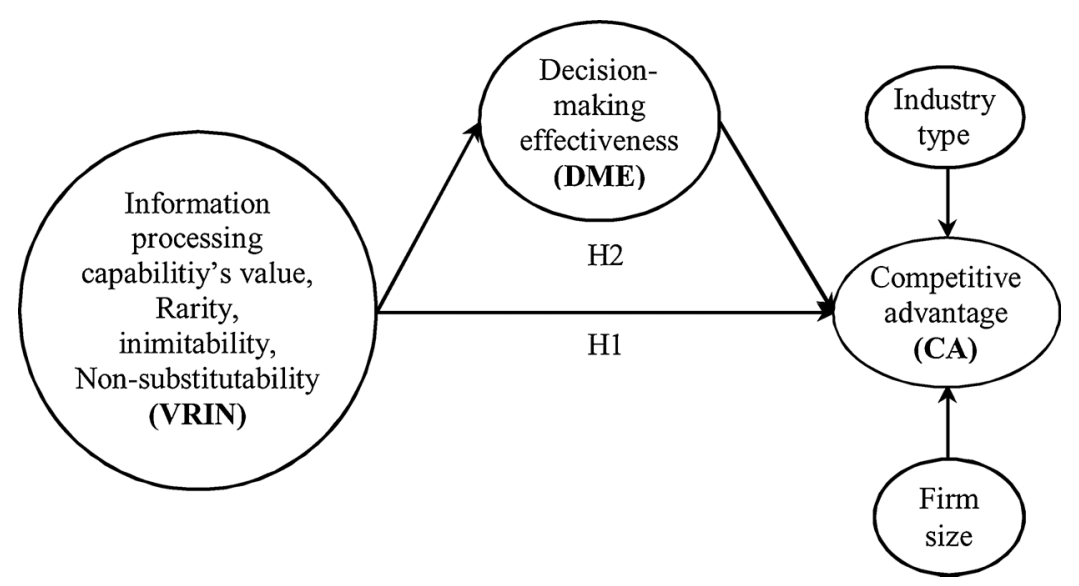

Fig. 1. Research model.

developed.

H1. Information processing capability's value, rarity, inimitability, and non-substitutability are positively linked to competitive advantage.

Another way to understand the link between information processing capability's VRIN conditions and competitive advantage is to examine whether and to what extent this link could be mediated through other organizational factors. Several conceptual studies suggest that there are factors that are likely to mediate the link between IT-related capabilities and competitive advantage (e.g. Sambamurthy et al., 2003; Melville et al., 2004; Kohli \& Grover, 2008) while a few empirical studies examine relevant mediators and their intervening impacts (e.g. Tippins \& Sohi, 2003; Ravichandran et al., 2005; Pavlou \& El Sawy, 2006). Building upon these studies and considering what might mediate the link between information processing capability and competitive advantage, the work of Cao et al. (2015) is interesting as it shows that information processing capability, resulted from the combined result of business analytics and a data-driven environment, is positively related to decision-making effectiveness. Additionally, other studies on business analytics suggest that firms that are adept at capturing and managing data can identify and embed analytic insights into business processes and operations, thereby to make data-driven decisions that are related to competitive advantage (Chen et al., 2015; Davenport, 2013b; Kiron et al., 2012; Lavalle et al., 2011) or innovation (Kiron et al., 2014). These studies suggest that information processing capability is closely associated with decision-making and competitive advantage, though the exact interrelation between them is unclear.

Moreover, IT-related research also supports the association between information processing capability and decision-making effectiveness implicitly (e.g. Huber, 1990; Molloy \& Schwenk, 1995; Chin \& Kotak, 2006; Wong, Lai, Cheng, \& Lun, 2015). Huber (1990) for example proposes a theory of the effects of advanced IT on organizational design, intelligence, and decision making, which suggests that use of advanced IT with storage capacity, transmission capacity, and processing capacity leads to increased information accessibility and changes in organizational design and finally improvements in effectiveness of decision making. Similarly, Molloy and Schwenk (1995) demonstrate that the use of IT for "the acquisition, storage, processing and communication of information" (p.285) improves decision-making efficiency and effectiveness; and Wong et al. (2015) find a positive relationship between inter-organizational information processing and collaborative decision making.

Furthermore, research on strategic decision-making provides additional support for the relationship between decision-making effectiveness and firm performance. Knowledge accumulated in this area suggests that companies having complete and accurate information about the likely relationship between choices and outcomes enable them to improve strategic decision effectiveness (Elbanna \& Child, 2007), make consistently sound and rational choices (Bonabeau, 2003), or improve the quality of strategic decisions (Borison \& Hamm, 2010). However, the economic outcomes of decision-making remain unclear (Rajagopalan, Rasheed, \& Datta, 1993; Shepherd \& Rudd, 2014). A few studies show that strategic decision-making positively predicts subsequent firm performance (e.g. Nayyar \& Bantel, 1994; Andersen, 2004; Kang \& Montoya, 2014). On the other hand, Fredrickson and Iaquinto (1989) show that strategic decision process is related to organizational performance positively in a stable environment but negatively in an unstable environment. Similarly, Goll and Rasheed (2005) find that the relationship between rational decision making and firm performance is strong and positive in high-munificence environments (measured as the growth rate in the industry) but is negative and not significant in lowmunificence environments.

To sum up, prior studies have suggested that pairwise relationships exist between information processing capability, decision-making effectiveness, and competitive advantage. Building on these pairwise relationships, this study goes one step further to conceptualize a mediation relationship between information processing capability, decisionmaking effectiveness, and competitive advantage. In addition to assume a direct link between information processing capability's VRIN conditions and competitive advantage, it is seen to be plausible and pertinent to postulate that information processing capability enhances decisionmaking effectiveness, which in turn become a source of competitive advantage. Thus, this article conjectures that:

H2. Decision-making effectiveness mediates the link between information processing capability's value, rarity, inimitability and non-substitutability and competitive advantage.

As a result, a mediation model is summarized and presented in Fig. 1.

The key variables include: VRIN-information processing capability's value, rarity, inimitability, non-substitutability; DME-decision-making effectiveness; and CA-competitive advantage. Additionally, prior research indicates that factors affecting firm performance can be different across industries (e.g. Mueller, Mone, \& Barker Ill, 2007; Miller, 2008) and may vary by company size (e.g. Baum \& Wally, 2003; Mueller et al., 2007). Therefore, this paper followed prior studies in controlling for firm size and industry type.

\section{Research methodology}

\subsection{Research model constructs and measures}

To develop and test the research model, the constructs and their associated measures were identified and summarized in Table 1. 
Table 1

Constructs and indicators of the study.

\begin{tabular}{|c|c|c|}
\hline Constructs & Indicators & References \\
\hline $\begin{array}{l}\text { VRIN } \\
\text { (Formative) }\end{array}$ & $\begin{array}{l}\text { Value } \\
\text { Rarity } \\
\text { Inimitability } \\
\text { Non-substitutability }\end{array}$ & Self-developed \\
\hline $\begin{array}{l}\text { Value } \\
\qquad \text { (Reflective) }\end{array}$ & $\begin{array}{l}\text { To what extent do you agree or disagree in your organization } \\
\text { Information processing capability is useful (VALUE1) } \\
\text { Information processing capability is important (VALUE2) } \\
\text { Information processing capability is valuable (VALUE3) }\end{array}$ & Nevo and Wade (2011) \\
\hline $\begin{array}{l}\text { Rarity } \\
\quad \text { (Reflective) }\end{array}$ & $\begin{array}{l}\text { To what extent do you agree or disagree } \\
\text { Others unlikely to have similar information processing capability like ours } \\
\text { (RARE1) } \\
\text { We have unique information processing capability (RARE2) } \\
\text { Few have as effective information processing capability like ours (RARE3) }\end{array}$ & Nevo and Wade (2011) \\
\hline $\begin{array}{l}\text { Inimitability } \\
\quad \text { (INIMI) } \\
\quad \text { (Reflective) }\end{array}$ & $\begin{array}{l}\text { To what extent do you agree or disagree } \\
\text { Our information processing capability cannot be easily replicated (INIMI1) } \\
\text { Few can match our information processing capability (INIMI2) }\end{array}$ & Nevo and Wade (2011) \\
\hline $\begin{array}{l}\text { Non-substitutability } \\
\text { (NON) } \\
\quad \text { (Reflective) }\end{array}$ & $\begin{array}{l}\text { To what extent do you agree or disagree } \\
\text { We could replace our current information processing capability with } \\
\text { alternative solution (NON1) }\end{array}$ & Nevo and Wade (2011) \\
\hline $\begin{array}{l}\text { Decision Making Effectiveness (DME) } \\
\quad \text { (Formative) }\end{array}$ & $\begin{array}{l}\text { We are more effective than our competitors at } \\
\text { Responding quickly to change (CHA1) } \\
\text { Making real-time decisions(RDM1) } \\
\text { Understanding customers (CUS1) }\end{array}$ & $\begin{array}{l}\text { Eisenhardt and Zbaracki (1992); Lessard \& Zaheer, 1996; } \\
\text { Cao et al. (2015) }\end{array}$ \\
\hline $\begin{array}{l}\text { Perceived Competitive advantage (CA) } \\
\quad \text { (Reflective) }\end{array}$ & $\begin{array}{l}\text { We are more effective than our competitors at } \\
\text { Increasing sales (SALE1) } \\
\text { Increasing revenue (REV1) } \\
\text { Generating profit (PROF1) } \\
\text { Providing product at a lower cost (COST1) }\end{array}$ & Schilke (2014); Cao et al. (2015); Lazzarini (2015) \\
\hline
\end{tabular}

Regarding measuring the VRIN conditions, few empirical studies underpinned by the RBV have operationalized and tested part or all of the VRIN conditions, except for only a few (Autio et al., 2000; Markman et al., 2004; Nevo \& Wade, 2011). This study measured information processing capability's VRIN by modifying the VRIN indicators developed by Nevo and Wade (2011). Specifically, this study self-developed a single higher-order VRIN construct defined by the four VRIN conditions formatively and collectively. This parsimonious construct seems to be pertinent based on the widely accepted assumption of the RBV that the sources of competitive advantage come from the position of VRIN resources and/or capabilities (Barney, 1991; Kraaijenbrink et al., 2010).

Decision-making effectiveness was measured formatively in terms of whether a company is more effective than its competitors at understanding customers, making real-time decisions, and responding quickly to change (Cao et al., 2015), which is consistent with research on strategic decision-making (Eisenhardt \& Zbaracki, 1992; Lessard \& Zaheer, 1996).

Perceived relative competitiveness has been commonly used to measure competitive advantage reflectively by prior studies (e.g. Chan, Sabherwal, \& Thatcher, 2006; Kearns \& Sabherwal, 2007). Based on relevant research (Cao et al., 2015; Lavalle et al., 2011; Lazzarini, 2015; Schilke, 2014), competitive advantage was measured in terms of manager's perception of whether his/her company is more effective than its competitors at reducing cost, increasing sales, generating revenue and profits, and providing product at a lower cost.

While VRIN and decision-making effectiveness were measured formatively, the rest of the constructs were measured reflectively based on the four decision rules suggested by Petter, Straub, and Rai, (2007): the direction of causality between construct and indicators, the interchangeability of indicators, the covariation among indicators, and the nomological net for the indicators. This helps define the constructs appropriately thereby to reduce the chances of improperly defining constructs that may damage the validity of the constructs and statistical conclusions (MacKenzie, Podsakoff, \& Podsakoff, 2011) and/or affect theory development and testing (Petter et al., 2007).

Additionally, this article followed prior studies (e.g. Baum \& Wally,
2003; Mueller et al., 2007; Miller, 2008) in controlling for firm size and industry type, which were categorical and measured by the use of dummy variables.

\subsection{Data collection}

To test the hypotheses empirically, medium-sized (employees between 50 and 250) and large UK companies (more than 250 employees) were selected as the target population since they are expected to have the capabilities and substantial resources to employ business analytics for business improvement (Gillon, Aral, Ching-Yung, Mithas, \& Zozulia, 2014). A questionnaire survey was generated using a five-point Likert scale (most of them ranging from strongly disagree to strongly agree) to provide responses to the model indicators of all constructs. The survey instruments were piloted and then delivered electronically through Qualtrics to managers, whose email addresses were identified from FAME (Financial Analysis Made Easy) database. The responding was voluntary without prior consent. Three rounds, four weeks apart, of emails including a cover letter with a questionnaire were sent. Each intended respondent was offered a summary of the results. While a total of 103,000 emails were sent with the e-mail subject highlighted as questionnaire survey, it was not known how many of them were opened as Qualtrics does not record the number of e-mails opened. Of all sent surveys, 2276 were opened, representing a click-through rate of $2.2 \%$; of these surveys opened, 633 usable responses were received. The response rate was not calculated as the literature does not seem to have provided agreed methods for doing this with mass email surveys such as the survey conducted by this research. Besides, Qualtrics does not provide data about the number of emails opened, which makes it impossible to calculate the response rate meaningfully.

\section{Results}

Initial data screening was performed using SPSS21 and the hypotheses were tested empirically using partial least squares structural equation modeling (PLS-SEM) based on survey data. 
Table 2

Respondent profiles $(\mathrm{n}=633)$.

\begin{tabular}{|c|c|c|c|c|c|c|}
\hline \multirow[t]{2}{*}{ Industry } & \multirow[t]{2}{*}{$\%$} & \multirow[t]{2}{*}{ Respondent Positions } & \multirow[t]{2}{*}{$\%$} & \multicolumn{3}{|c|}{ Respondent Experience } \\
\hline & & & & Years (x) & In the firm \% & In the industry $\%$ \\
\hline Manufacturing & 31 & CEO/MD/Partner & 28 & $x \leq 5$ & 22 & 4 \\
\hline Prof Services & 15 & Finance/Accounting director & 13 & $5<x \leq 10$ & 29 & 10 \\
\hline Retail/Wholesale & 8 & Operations director & 11 & $10<x \leq 15$ & 13 & 12 \\
\hline Technology & 7 & Marketing/Sales director & 11 & $15<\mathrm{x} \leq 20$ & 12 & 15 \\
\hline Fin Services & 6 & CIO/IT Manager & 8 & $20<\mathrm{x} \leq 25$ & 10 & 14 \\
\hline Other & 33 & Other directors & 29 & $x>25$ & 14 & 45 \\
\hline
\end{tabular}

\subsection{Respondents}

Table 2 summarizes the respondents' characteristics in terms of their organizational positions and years of experience in their current firms and industries.

The reported positions of the respondents suggested that $28 \%$ of the respondents were in a senior managerial position and the rest of them were in a middle managerial position. Based on their positions within the firm, the respondents were highly likely to participate in decisionmaking processes related to the topic of the survey in terms of a key informant approach (Bagozzi, Youjae, \& Phillips, 1991; Phillips \& Bagozzi, 1986). Of all respondents, $49 \%$ had been with their firms for more than 10 years, whilst $86 \%$ had been in their industries for more than 10 years. $69.5 \%$ and $30.5 \%$ of the respondents were from mediumsized and large companies correspondingly. The respondents were also from a number of different industries. Overall, the sample of respondents seemed to be diverse, representing various industries, managerial positions and experiences.

\subsection{Common method and non-respondent bias}

In order to control for common method bias that may affect the correlations between variables and cause biased parameter estimates (Malhotra, Patil, \& Kim, 2007), this research used both procedural and statistical remedies. The first procedural remedy was to improve scale items through defining terms clearly, keeping the questions simple and specific, and labeling every point on the response scale (Krosnick, 1999). Another procedural remedy used was to balance positively and negatively worded measures to control for acquiescence and disacquiescence biases (Podsakoff, MacKenzie, \& Podsakoff, 2012). Additionally, Harman's single-factor was conducted as a statistical remedy to assess common method bias by entering all independent and dependent variables (Podsakoff, MacKenzie, Lee, \& Podsakoff, 2003). If a single factor explains most of the variance of all the indicators, then common method bias associated with the data is high. Conversely, if more than one factor emerges to explain most of the variances, then the common method variance is low. As the first factor accounted for $28.80 \%$ of the total variance, there was no evidence of a substantial respondent bias in this study.

To evaluate the presence of non-response bias, two tests were conducted. The first test compared the distributions of the company size of the respondents with that of the complete sampling frame, based on the known value for the population approach (Armstrong \& Overton, 1977). In Table 3, the number of the respondents is the observed value, while the number of the full sampling frame is the expected value. If the

Table 3

Expected and observed value.

\begin{tabular}{llll}
\hline Company size & Observed value & Expected value & Residual \\
\hline Medium & 440 & 424 & 16 \\
Large & 193 & 209 & -16 \\
\hline
\end{tabular}

Chi-square test $p$-value $=0.1762$. observed and the expected values are significantly different, there is a bias between respondents and non-respondents. A nonparametric chisquare test comparing the distributions of the observed and expected values found no significant differences.

Non-response bias was then assessed by comparing early and late respondents on all measures through a $t$-test, based on the premise that early respondents represent the average respondent while late respondents represent the average non-respondent (Armstrong \& Overton, 1977). Based on the two tailed significance level and the Levene's $t$-test, the results did not find significant differences between the two respondent groups, suggesting an absence of non-response bias.

\subsection{Sample size and data screening}

740 responses were initially received and data screening was performed using SPSS21. Missing data for an observation exceeding $10 \%$ was first removed. The remaining data with missing values were checked if they were missing completely at random (MCAR) (Little, 1988) and those with a significant Little's MCAR test were deemed nonrandom and removed. The final responses used in the analysis were 633.

The maximum number of arrows pointing at a construct is four in the structural model of this research. In order to detect a minimum $\mathrm{R}^{2}$ value of 0.10 in any of the constructs for significant level of $1 \%$, the minimum sample size required is 191 (Hair, Hult, Ringle, \& Sarstedt, 2014). Since 633 usable responses were collected, the minimum sample size requirement is thus met.

\subsection{Evaluation of the reflective measurement model}

Since the PLS-SEM includes both formative and reflective constructs, they were evaluated separately following different processes and criteria. First, the reflective measurement model was evaluated by considering the internal consistency (composite reliability), indictor reliability, convergent validity and discriminant validity, following the recommendations made by Hair et al. (2014). All constructs were validated except for NON as its path coefficient was close to zero and was not statistically significant. Composite reliability (CR) scores summarized in Table 4 indicated that results based on these constructs should be consistent on the whole. All constructs met the recommended threshold value for acceptable reliability, that is, both CR and Cronbach's $\alpha$ should be large than 0.70 .

Discriminant validity was satisfactory based on two tests conducted. The first test was to analyze the Fornell-Larcker criterion to evaluate if the square root of AVE value for each construct was greater than the correlation of the construct with any other construct (Hair et al., 2014), which was true based on the comparison summarized in Table 5. The second test was to observe if each reflective indicator loaded highest on the construct it was associated with, which was also true, thus demonstrating discriminant validity was satisfactory. 
Table 4

Convergent Validity and Internal Consistency Reliability.

\begin{tabular}{lllllll}
\hline Construct & Indicator & Loading & $\begin{array}{l}\text { Indicator } \\
\text { Reliability }\end{array}$ & $\begin{array}{l}\text { Composite } \\
\text { Reliability }\end{array}$ & Cronbach's $\alpha$ & AVE \\
\hline \multirow{2}{*}{ CA } & COST1 & 0.79 & 0.62 & 0.91 & 0.87 & 0.72 \\
& PROF1 & 0.84 & 0.71 & & & \\
& REV1 & 0.89 & 0.79 & & & \\
& SALE1 & 0.88 & 0.77 & & 0.72 & 0.78 \\
INIMI & INIMI1 & 0.90 & 0.81 & 0.88 & & \\
& INIMI2 & 0.87 & 0.76 & & & \\
NON & Non1 & 1.00 & 1.00 & 1.00 & 1.00 & 0.68 \\
RARITY & RARE1 & 0.76 & 0.58 & 0.87 & 0.77 & \\
& RARE2 & 0.88 & 0.77 & & & \\
& RARE3 & 0.83 & 0.69 & & & \\
VALUE & VALUE1 & 0.93 & 0.86 & 0.95 & 0.93 & \\
& VALUE2 & 0.95 & 0.90 & & & \\
& VALUE3 & 0.93 & 0.86 & & & \\
\hline
\end{tabular}

Table 5

Inter-construct correlations.

\begin{tabular}{llll}
\hline & CA & DME & VRIN \\
\hline CA & $\mathbf{0 . 8 5}$ & & \\
DME & 0.76 & a & \\
VRIN & 0.58 & 0.61 & $\mathbf{0 . 6 8}$ \\
\hline
\end{tabular}

${ }^{\mathrm{a}}$ formative.

\subsection{Assessment of formative measurement model}

The formative measurement model was evaluated in terms of assessing the indicator weights, significance of weights, the indictor loadings, and multicollinearity (Hair et al., 2014). Based on bootstrapping (5000 samples), all formative indictors' outer loadings, outer weights and the associated significance testing t-values were assessed, which are summarized in Table 6.

Following the procedure suggested by Hair et al. (2014), all indicators' outer weights were satisfactory, indicating that these formative indictors truly contribute to forming their associated constructs. To assess the level of multicollinearity, the values of variance inflation factor (VIF) of all formative constructs were evaluated. Based on Petter et al. (2007) and Hair et al. (2014), all VIF values were acceptable and there were no collinearity issues.

\subsection{Evaluation of the structural model}

SmartPLS 3 was used for testing the hypotheses and assessing the predictive power of the research model and the results of the analysis are presented in Fig. 2.

The model's predictive accuracy was reflected by the variables' $R^{2}$ values. When PLS-SEM is used, the effect size defined for $\mathrm{R}^{2}$ is small $=0.1$, medium $=0.25$, and large $=0.36$ (Wetzels, OdekerkenSchröder, \& van Oppen, 2009). In line with this, the effect sizes of CA and DME were large. Table 7 shows the standardized path coefficients of each hypothesized path of the theoretical model (excluding the control variables) and the full model including all variables. The two control variables are all statistically significant and have an effect on

Table 6

Outer Weights \& Significance Testing Results.

\begin{tabular}{|c|c|c|c|c|}
\hline $\begin{array}{l}\text { Formative } \\
\text { Construct }\end{array}$ & $\begin{array}{l}\text { Formative } \\
\text { Indicators }\end{array}$ & $\begin{array}{l}\text { Outer } \\
\text { Weights }\end{array}$ & $p$-values & $\begin{array}{l}\text { Outer } \\
\text { Loadings }\end{array}$ \\
\hline \multirow[t]{3}{*}{ DME } & CHA1 & 0.37 & $0.000^{* * * * k}$ & $0.92^{* * * x}$ \\
\hline & CUS1 & 0.37 & $0.000^{k * * *}$ & $0.90^{\text {***** }}$ \\
\hline & RTD1 & 0.36 & $0.000^{* * * k}$ & $0.92^{k * * *}$ \\
\hline
\end{tabular}

$\mathrm{p}<0.001,{ }^{* *} \mathrm{p}<0.01,{ }^{*} \mathrm{p}<0.05,{ }^{\mathrm{ns}}$-not significant. competitive advantage.

\subsection{Hypotheses testing and mediation analysis}

Hypothesis 1 suggests that information processing capability's VRIN has a direct effect on competitive advantage (CA), which was supported since VRIN's direct effect on CA is $0.169(p<0.001)$ while non-substitutability was not validated.

To verify H2, the mediating role of DME on the relationship between VRIN and CA was analyzed and summarized in Table 8, following the recommendations made by Baron and Kenny (1986) while the analysis was based on bootstrapping (Hair et al., 2014). To begin the analysis, the direct relationship between VRIN and CA was estimated, which was significant. Then the mediator, DME, was included to analyze whether the indirect effect of VRIN via DME on CA was significant. The evaluation indicated that the significance of the relationship between VRIN and DME (0.61), as well as between DME and CA (0.52). Thus, the indirect effect of VRIN via DME on CA was 0.317 $(0.61 \times 0.52)$, and its significance was confirmed by calculating the empirical $p$ value of the indirect effect based on the 5000 bootstrapping results. The relative size of the mediating effect was decided by calculating the variance accounted for (VAF) based on Shrout and Bolger (2002), which suggested that DME partially but strongly mediated the effect of VRIN on CA; thus Hypothesis 2 is supported.

\section{Discussion and conclusion}

The main objective of this article was to examine if there is a link between information processing capability's VRIN conditions and competitive advantage and whether and to what extent this link is mediated through decision-making effectiveness. The mediation model proposed was empirically tested and the hypotheses were supported.

\subsection{Key findings and discussion}

While many IT-related studies underpinned by the RBV show that there is a direct link between IT-enabled organizational capabilities and competitive advantage (e.g. Barua et al., 2004; Peppard \& Ward, 2004; Lim et al., 2011), such a direct link is seen to "obviously lacks face validity" (Ketchen et al., 2007, p.962), create a black box issue (Kraaijenbrink et al., 2010; Priem \& Butler, 2001; Sirmon et al., 2007), and/or neglect the socially embedded qualities of organizational capabilities (Scarbrough, 1998). Rather than assuming a direct link between information processing capability and competitive advantage that is seen to be problematic, this study has examined this link by operationalizing and testing information processing capability's VRIN conditions as a whole. The research finding shows that this is supported (H1: path coefficient $=0.169, p<0.001$ ), suggesting that a firm can gain competitive advantage from its information processing capability if it is simultaneously valuable, rare, and inimitable.

While this finding is seen to be largely consistent with prior studies underpinned by the RBV that support the direct link between IT-enabled organizational capabilities and competitive advantage (e.g. Bharadwaj, 2000; Barua et al., 2004; Mithas et al., 2012), this study is also rather different. By operationalizing and testing the VRIN conditions of information processing capability, this study provides both conceptual and empirical evidences to explain why information processing capability is likely to be a source of competitive advantage. In particular, this seems to suggest that the link between the VRIN conditions of information processing capability and competitive advantage could be a more useful relationship to be investigated as it addresses the black box issue to a certain degree. By specifically examining the VRIN conditions empirically, this study has looked into the socially embedded qualities (Scarbrough, 1998) of information processing capability in terms of for example developing a data-driven environment (Cao et al., 2015), buyer-supplier relation (Chen et al., 2015), 


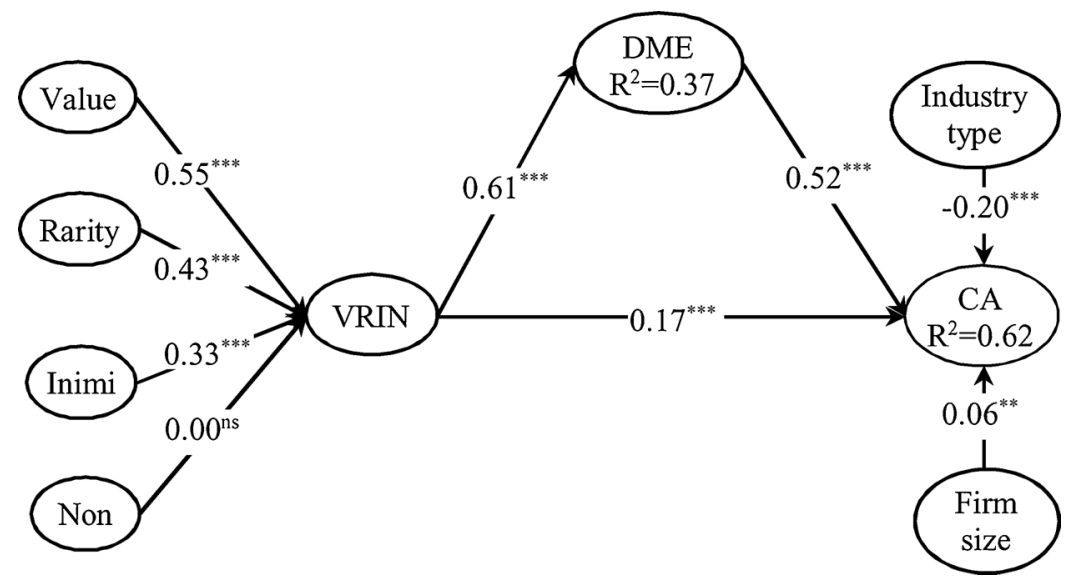

Fig. 2. Path analysis results.

Table 7

Summary Results of Path Analysis.

\begin{tabular}{|c|c|c|}
\hline \multirow[t]{2}{*}{ Path } & \multicolumn{2}{|l|}{ Path Coefficients } \\
\hline & Theoretical model (a) & Full model (b) \\
\hline VRIN $\rightarrow$ DME & $0.609^{\text {*k*k }}$ & $0.609^{* * * *}$ \\
\hline $\mathrm{DME} \rightarrow \mathrm{CA}$ & $0.646^{* 2 \times k t}$ & $0.516^{* k *}$ \\
\hline $\mathrm{VRIN} \rightarrow \mathrm{CA}$ & $0.189^{* * * *}$ & $0.169^{k * k x}$ \\
\hline \multirow[t]{2}{*}{ Control variable } & Firm size $\rightarrow$ CA & $0.064^{* * *}$ \\
\hline & Industry type $\rightarrow \mathrm{CA}$ & $-0.200^{k \cdot k * *}$ \\
\hline$\Delta \mathrm{R}^{2}$ value for $\mathrm{CA}$ & $\Delta \mathrm{R}^{2}=0.624_{\mathrm{b}}-0.601_{\mathrm{a}}$ & \\
\hline
\end{tabular}

${ }^{* * *} \mathrm{p}<0.001,{ }^{* *} \mathrm{p}<0.01,{ }^{*} \mathrm{p}<0.05,{ }^{\mathrm{ns}}$-not significant.

Table 8

The Mediation of DME on the Relationship between VRIN and CA.

\begin{tabular}{llllll}
\hline Hypothesis & $\begin{array}{l}\text { Direct effect } \\
\text { without } \\
\text { mediation }\end{array}$ & $\begin{array}{l}\text { Direct effect } \\
\text { with } \\
\text { mediation }\end{array}$ & $\begin{array}{l}\text { Indirect } \\
\text { effect }\end{array}$ & VAF & $\begin{array}{l}\text { Mediation } \\
\text { type observed }\end{array}$ \\
\hline Hypothesis 2 & $0.382^{\text {***** }}$ & $0.169^{\text {***** }}$ & $0.317^{\text {**** }}$ & 0.65 & Partial \\
\hline
\end{tabular}

${ }^{* * *} \mathrm{p}<0.001,{ }^{* *} \mathrm{p}<0.01,{ }^{*} \mathrm{p}<0.05 \mathrm{VAF}>0.80$ full mediation, $0.20 \leq \mathrm{VAF}$ $\leq 0.80$ partial mediation, $\mathrm{VAF}<0.20$ no mediation.

"analytically driven strategy" (Davenport \& Harris, 2007, p.10), relevant business processes (Barton \& Court, 2012) or organizational structure (Acito \& Khatri, 2014). By conceptualizing and testing the VRIN conditions of information processing capability, this study helps explain why competitive advantage could be gained from information processing capability. As a result, the research finding provides not only empirical evidence but also conceptual support for the competitive impact of information processing capability, which could be seen as a response to some of the criticism levied at the RBV such as lacking validity and theoretical support (Kraaijenbrink et al., 2010; Priem \& Butler, 2001; Sirmon et al., 2007). Thus, this research finding arguably provides support for the RBV in general and the usefulness of the VRIN conditions in particular, and suggests that conceptualizing and testing the relationship between the VRIN conditions of IT-related capabilities and competitive advantage could be more fruitful.

Contrary to expectations, the path leading from non-substitutability to VRIN is not statistically significant and thus not included in the research's final analysis. Similarly, the paths leading from non-substitutability are not statistically significant in Nevo and Wade (2011). It seems that more research is needed to further examine this phenomenon as it is unclear whether this is due to only one indicator being used to measure non-substitutability or conceptual issues with non-substitutability. For instance, Newbert (2007) suggests that non-substitutability is merely a form of inimitability while Nevo and Wade (2010) argue that there is no logical reason to hypothesize that IT-related resources are non-substitutable.

With respect to the hypothesis on the mediating role of decisionmaking effectiveness, the result of the mediation model suggests that decision-making effectiveness partially and strongly mediates the link between the VRIN conditions of information processing capability and competitive advantage $(\mathrm{H} 2$ : $\mathrm{VAF}=0.65, p<0.001)$. This mediating effect shows that decision-making effectiveness is an important intervening process for information processing capability's VRIN to impact on competitive advantage indirectly. Essentially, this implies that information processing capability's VRIN has a positive effect on decisionmaking effectiveness, which in turn has a positive effect on competitive advantage.

First, the finding confirms that information processing capability's VRIN conditions as a whole plays an important role in improving decision-making effectiveness. This is believable because by developing the ability to capture, integrate, and analyze data/information, and utilize information and insights, a firm will be able to match its information processing requirements with information processing capabilities thereby to be more effective at understanding its customers, making real-time decisions, and responding more quickly to increasing competition and other business challenges. This is consistent with and provides support for practice-oriented studies on business analytics (e.g. Kiron \& Shockley, 2011; Lavalle et al., 2011; Kiron et al., 2012) that suggest that firms that are adept at capturing and managing data can identify and embed analytic insights into business processes and operations, thereby to make data-driven decisions. This finding also provides empirical evidence in support of the theory of the effects of advanced IT on organizational design, intelligence, and decision making developed by Huber (1990) and is consistent with Molloy and Schwenk (1995) and Bhatt, Emdad, Roberts, and Grover, (2010) regarding the impact of information processing capability on decisionmaking efficiency and organizational responsiveness respectively.

Second, the finding from this research suggests that a firm can attain competitive advantage from better understanding its customers, making real-time decisions, and responding quickly to change. For example, prior research suggests that in order for a firm to be in a relatively better competitive position, it is necessary for the firm to be able to respond to global competition and technological change and to understand customers (Davenport, Mule, \& Lucker, 2011; Verhoef \& Lemon, 2013; Woodruff, 1997). When a firm can understand its customer better, it will be able to attract new customers, increase customer loyalty and retention, and provide products and services customers want (e.g. Davenport, 2006; Kiron \& Shockley, 2011; Lavalle et al., 2011; Davenport, 2013a). When a firm is able to make quick decisions and respond quickly, the firm could respond to changing customer needs quickly and reduce cycle time in all aspects of a business thereby 
to provide greater value to its customers and improving the quality of organizational processes.

Third, this finding adds to the limited body of empirical evidence that exists to examine relevant mediators and their impacts by specifying that decision-making effectiveness as a mediator intervenes the link between the VRIN conditions of information processing capability and competitive advantage; thus it provides additional evidence in support of conceptual research suggesting that factors may exist to mediate the link between IT-related capabilities and competitive advantage (e.g. Sambamurthy et al., 2003; Melville et al., 2004; Kohli \& Grover, 2008).

Additionally, this finding provides strong conceptual and empirical support for business analytics research (e.g. Lavalle et al., 2011; Kiron et al., 2012; Davenport, 2013a) by explicitly linking decision-making effectiveness to competitive advantage positively. The finding also adds additional empirical evidence in support of the positive relationship between decision-making effectiveness and firm performance in the literature on strategic decision-making, which is seen to remain unclear (Rajagopalan et al., 1993; Shepherd \& Rudd, 2014).

\subsection{Theoretical contributions}

Therefore, this research mainly contributes to the theoretical development of the RBV by developing a mediation model that looks inside the black box and reveals that the path from information processing capability to competitive advantage is more complex than the direct link between capabilities and competitive advantage demonstrated in other research contexts (Newbert, 2007). The mediation model takes one step further by showing that not only there is a positive link between information processing capability's VRIN conditions and competitive advantage but also this link could be strongly mediated through decision-making effectiveness. Thus, the findings from this research make an original contribution to the RBV by providing an alternative explanation for, and new insight into, how information processing capability, or other IT-related capabilities, may create strategic value for a company. To the best of the authors' knowledge, this mediation model has not been conceptualized and tested by others although a number of researchers were unsatisfied with only examining the direct link from resources and capabilities to competitive advantage (MacKinnon, 2008; Markman et al., 2004; Newbert, 2007).

Second, this study contributes to IT-related studies by providing conceptual and empirical evidences in support of research suggesting that the link between IT-related capabilities and competitive advantage could be mediated (e.g. Sambamurthy et al., 2003; Melville et al., 2004; Kohli \& Grover, 2008). This study also advances our understanding of the emerging ideas surrounding business analytics and its impact on organizations. While research on business analytics generally suggests that information processing capability helps improve decision-making and gain competitive advantage (e.g. Lavalle et al., 2011; Davenport, 2013a; Kiron et al., 2014), such a belief has rarely been examined based on testable hypotheses underpinned by theories.

Third, this research also contributes to the literature on strategic decision-making. By linking information processing capability to decision-making effectiveness, this study may stimulate others to further examine the link between organizational capabilities and strategic decision-making as organizational capabilities are rarely considered in the literature (Rajagopalan et al., 1993; Shepherd \& Rudd, 2014). Additionally, this research provides further empirical evidence in support of the positive relationship between strategic decision-making and firm performance (e.g. Nayyar \& Bantel, 1994; Andersen, 2004; Kang \& Montoya, 2014).

\subsection{Implications for practice}

While IT has become "a ubiquitous and increasingly significant part of the fabric of most organizations" (Doherty, Champion, \& Wang,
2010, p. 116), understanding how IT-enabled capabilities contribute to competitive performance has been a complex issue (Farbey et al., 1994; Melville et al., 2004) and still remains a challenging task (Cao et al., 2016; Kim et al., 2011; Kohli \& Grover, 2008). The findings from this research have provided managers with a deeper understanding of the mechanism through which the strategic value of information processing capability can be maximized. The research demonstrates that a firm can gain competitive advantage directly from developing valuable, rare, and inimitable information processing capability and indirectly from improving its decision-making effectiveness. By developing its information processing capability, the firm will be able to better capture, integrate, and analyze data/information, and utilize information and insights. This in turn will allow the company to have complete and accurate information about the likely relationship between choices and outcomes, such as better understanding customers, serving them better by developing products and services that customers want, thereby increasing customer loyalty. Consequently, the firm will be able to make consistently sound and rational choices, make decisions faster and timely than ever before, and act confidently and decisively in a fastpaced marketplace. This research suggests that firms should be incentivized to develop their information processing capability, thereby to improve their decision-making effectiveness and gain competitive advantage.

\subsection{Limitations and future research}

The study has several limitations. As there is only so much ground that a single study can cover, a potential problem of this study relates to the possibilities of disregarding relevant factors in this research. For example, this research did not incorporate the concept of environmental dynamism to consider its moderating effect on the relationship between strategic decision making and performance suggested by Goll and Rasheed (1997) nor top management team to reflect its moderating effect on the relationship between IT resources and competitive advantage suggested by Wade and Hulland (2004). The rationale for this omission was that the focus was on conceptualizing and empirically testing whether there is a mediation relationship between information processing capability, decision-making effectiveness, and competitive advantage. Thus, there might be biases resulting from excluding other salient variables in the context of this particular study; the findings from this research should be interpreted with this potential problem in mind.

While this research has demonstrated that there is a positive link between information processing capability's VRIN conditions and competitive advantage, which is mediated through decision-making effectiveness, this understanding could be further advanced by including more organizational and decision-making variables. Nevertheless, whether decision-making effectiveness mediates the relationship between other capabilities and competitive advantage remains to be explored.

Additionally, future research could test the mediation model in other sectors and countries as this study is based on data collected in the UK. Future research could also use objective measures such as firm market share to complement perceived measurements of competitive advantage used in this study.

\subsection{Conclusion}

Drawing on the resource-based view, this study has articulated and tested a research model for understanding the interrelationships among information processing capability, decision-making effectiveness, and competitive advantage. Most importantly, the current study shows that there is a positive link between the value, rarity and inimitability characteristics of information processing capability and competitive advantage, which is mediated by decision-making effectiveness. This study also helps firms understand the mechanism of gaining 
competitive advantage from information processing capability.

\section{References}

Acito, F., \& Khatri, V. (2014). Business analytics: Why now and what next? Business Horizons, 57(5), 565-570.

Andersen, T. J. (2004). Integrating decentralized strategy making and strategic planning processes in dynamic environments. Journal of Management Studies, 41(8), 1271-1299.

Armstrong, J. S., \& Overton, T. S. (1977). Estimating nonresponse bias in mail surveys. Journal of Marketing Research (JMR), 14(3), 396-402.

Autio, E., Sapienza, H. J., \& Almeida, J. G. (2000). Effects of age at entry, knowledge intensity, and imitability on international growth. Academy of Management Journal, 43(5), 909-924.

Bagozzi, R. P., Youjae, Y., \& Phillips, L. W. (1991). Assessing construct validity in organizational research. Administrative Science Quarterly, 36(3), 421-458.

Barney, J. (1991). Firm resources and sustained competitive advantage. Journal of Management, 17(1), 99-120.

Baron, R. M., \& Kenny, D. A. (1986). The moderator-mediator variable distinction in social psychological research - Conceptual, strategic, and statistical considerations. Journal of Personality and Social Psychology, 5(6), 1173-1182.

Barton, D., \& Court, D. (2012). Making advanced analytics work for you. Harvard Business Review, 90(10), 78-83.

Barua, A., Konana, P., Whinston, A. B., \& Fang, Y. (2004). An empirical investigation of net-enabled business value. MIS Quarterly, 28(4), 585-620.

Baum, J. R., \& Wally, S. (2003). Strategic decision speed and firm performance. Strategic Management Journal, 24(11), 1107-1129.

Bharadwaj, A. S. (2000). A resource-based perspective on information technology capability and firm performance: An empirical investigation. MIS Quarterly, 24(1), 169-196.

Bhatt, G., Emdad, A., Roberts, N., \& Grover, V. (2010). Building and leveraging information in dynamic environments: The role of IT infrastructure flexibility as enabler of organizational responsiveness and competitive advantage. Information \& Management, 47(7/8), 341-349.

Bonabeau, E. (2003). Don't trust your gut. Harvard Business Review, 81(5), 116-123.

Borison, A., \& Hamm, G. (2010). Prediction markets: A new tool for strategic decision making. California Management Review, 52(4), 125-141.

Cao, G., Duan, Y., Cadden, T., \& Minocha, S. (2016). Systemic capabilities: The source of IT business value. Information Technology \& People, 29(3), 556-579.

Cao, G., Duan, Y., \& Li, G. (2015). Linking business analytics to decision making effectiveness: A path model analysis. IEEE Transactions on Engineering Management, 62(3), 384-395.

Chan, Y. E., Sabherwal, R., \& Thatcher, J. B. (2006). Antecedents and outcomes of strategic is alignment: An empirical investigation. IEEE Transactions on Engineering Management, 53(1), 27-47.

Chen, D. Q., Preston, D. S., \& Swink, M. (2015). How the use of big data analytics affects value creation in supply Chain management. Journal of Management Information Systems, 32(4), 4-39.

Chin, A. G., \& Kotak, H. (2006). Improving debt collection processes using rule-based decision engines: A case study of capital one. International Journal of Information Management, 26(1), 81-88.

Collins, C. J., \& Clark, K. D. (2003). Strategic human resource practices, top management team social networks, and firm performance: The role of human resource practices in creating organizational competitive advantage. Academy of Management Journal, 46(6), 740-751.

Davenport, T. H. (2006). Competing on analytics. Harvard Business Review, 84(1), 98-107.

Davenport, T. H. (2013). Analytics 3.0. Harvard Business Review, 91(12), 64-72.

Davenport, T. H. (2013b). Keep Up with your quants. Harvard Business Review, 91(7), $120-123$.

Davenport, T. H., \& Harris, J. G. (2007). Competing on analytics: The New science of winning. Boston, MA: Harvard Business School Review Press.

Davenport, T. H., Harris, J. G., De Long, D. W., \& Jacobson, A. L. (2001). Data to knowledge to results: Building an analytic capability. California Management Review, 43(2), 117-138.

Davenport, T. H., Mule, L. D., \& Lucker, J. (2011). Know what your customers want before they do. Harvard Business Review, 89(12), 84-92.

DeCarlo, T., Roy, T., \& Barone, M. (2015). How sales manager experience and historical data trends affect decision making. European Journal of Marketing, 49(9/10), 1484-1504.

Dillon, R. L., \& Tinsley, C. H. (2008). How near-misses influence decision making under risk: A missed opportunity for learning. Management Science, 54(8), 1425-1440.

Doherty, N. F., Champion, D., \& Wang, L. (2010). An holistic approach to understanding the changing nature of organisational structure. Information Technology \& People, 23(2), 116-135.

Dutta, D., \& Bose, I. (2015). Managing a big data project: The case of ramco cements limited. International Journal of Production Economics, 165, 293-306.

Eisenhardt, K. M., \& Martin, J. A. (2000). Dynamic capabilities: What are they? Strategic Management Journal, 21(10-11), 1105-1121.

Eisenhardt, K. M., \& Zbaracki, M. J. (1992). Strategic decision making. Strategic Management Journal, 13, 17-37.

Elbanna, S., \& Child, J. (2007). Influences on strategic decision effectiveness: Development and test of an integrative model. Strategic Management Journal, 28(4), 431-453.

Farbey, B., Targett, D., \& Land, F. (1994). Matching an IT project with an appropriate method of evaluation: A research note on 'Evaluating investments in IT'. Journal of
Information Technology, 9(3), 239-243.

Fink, L., \& Neumann, S. (2009). Exploring the perceived business value of the flexibility enabled by information technology infrastructure. Information \& Management, 46(2), 90-99.

Fredrickson, J. W., \& Iaquinto, A. L. (1989). Inertia and creeping rationality in strategic decision processes. Academy of Management Journal, 32(3), 516-542.

Galbraith, J. R. (1974). Organization design: An information processing view. Interfaces, $4(3), 28-36$.

Gillon, K., Aral, S., Ching-Yung, L., Mithas, S., \& Zozulia, M. (2014). Business analytics: Radical shift or incremental change? Communications of the Association for Information Systems, 34(1), 287-296.

Goll, I., \& Rasheed, A. A. (2005). The relationships between top management demographic characteristics, rational decision making, environmental munificence, and firm performance. Organization Studies (01708406), 26(7), 999-1023.

Goll, I., \& Rasheed, A. M. A. (1997). Rational decision-making and firm performance: The moderating role of environment. Strategic Management Journal, 18(7), 583-591.

Hair, J. F., Hult, G., Ringle, C., \& Sarstedt, M. (2014). A primer on partial least squares structural equation modeling (PLS-SEM). Sage.

Hammedi, W., Riel, A. C. R., \& Sasovova, Z. (2013). improving screening decision making through transactive memory systems: A field study improving screening decision making through transactive memory systems: A field study. Journal of Product Innovation Management, 30(2), 316-330.

Huber, G. P. (1990). A theory of the effects of advanced information technologies on organizational design, intelligence, and decision making. Academy of Management Review, 15(1), 47-71.

Kang, W., \& Montoya, M. (2014). The impact of product portfolio strategy on financial performance: The roles of product development and market entry decisions. Journal of Product Innovation Management, 31(3), 516-534.

Kearns, G., \& Sabherwal, R. (2007). Strategic alignment between business and information technology: A knowledge-based view of behaviors, outcome, and consequences. Journal of management information systems, 23(3), 129-162.

Ketchen, D. J., Hult, G. T. M., \& Slater, S. F. (2007). Toward greater understanding of market orientation and the resource-based view. Strategic Management Journal, 28(9), 961-964.

Kim, G., Shin, B., Kim, K. K., \& Lee, H. G. (2011). IT capabilities, process-oriented dynamic capabilities, and firm financial performance. Journal of the Association for Information Systems, 12(7), 487-517.

Kiron, D., Prentice, P. K., \& Ferguson, R. B. (2012). Innovating with analytics. MIT Sloan Management Review, 54(1), 47-52.

Kiron, D., Prentice, P. K., \& Ferguson, R. B. (2014). Raising the bar with analytics. MIT Sloan Management Review, 55(2), 29-33.

Kiron, D., \& Shockley, R. (2011). Creating business value analytics. MIT Sloan Management Review, 53(1), 57-63.

Kohli, R., \& Grover, V. (2008). Business value of IT: An essay on expanding research rirections to keep up with the times. Journal of the Association for Information Systems, 9(1), 23-39.

Kraaijenbrink, J., Spender, J. C., \& Groen, A. J. (2010). The resource-based view: A review and assessment of its critiques. Journal of Management, 36(1), 349-372.

Krosnick, J. A. (1999). Survey research. Annual Review of Psychology, 50(1), 537-567.

Lavalle, S., Lesser, E., Shockley, R., Hopkins, M. S., \& Kruschwitz, N. (2011). Special report: Analytics and the new path to value. MIT Sloan Management Review, 52(2), 22-32.

Lazzarini, S. G. (2015). Strategizing by the government: Can industrial policy create firmlevel competitive advantage? Strategic Management Journal, 36(1), 97-112.

Lessard, D. R., \& Zaheer, S. (1996). Breaking the silos: Distributed knowledge and strategic responses to volatile exchange rates. Strategic Management Journal, 17(7), 513-533.

Lim, J.-H., Stratopoulos, T. C., \& Wirjanto, T. S. (2011). Path dependence of dynamic information technology capability: An empirical investigation. Journal of Management Information Systems, 28(3), 45-84.

Lim, J.-H., Stratopoulos, T. C., \& Wirjanto, T. S. (2012). Role of IT executives in the firm's ability to achieve competitive advantage through IT capability. International Journal of Accounting Information Systems, 13(1), 21-40.

Little, R. J. (1988). A test of missing completely at random for multivariate data with missing values. Journal of the American Statistical Association, 83(404), 1198-1202.

MacKenzie, S. B., Podsakoff, P. M., \& Podsakoff, N. P. (2011). Construct measurement and validation procedures in MIS and behavioral research: Integrating new and existing techniques. MIS Quarterly, 35(2), 293-334.

MacKinnon, D. P. (2008). Introduction to statistical mediation analysis. Routledge.

Makadok, R. (2001). Toward a synthesis of the resource-based and dynamic-capability views of rent creation. Strategic Management Journal, 22(5), 387-401.

Malhotra, N. K., Patil, A., \& Kim, S. S. (2007). BIAS breakdown. Marketing Research, 19(1), 24-29.

Markman, G. D., Espina, M. I., \& Phan, P. H. (2004). Patents as surrogates for inimitable and non-substitutable resources. Journal of Management, 30(4), 529-544.

Melville, N., Kraemer, K., \& Gurbaxani, V. (2004). Information technology and organizational performance: An integrative model of IT business value. MIS Quarterly, 28(2), 283-322.

Miller, C. C. (2008). Decisional comprehensiveness and firm performance: Towards a more complete understanding. Journal of Behavioral Decision Making, 21(5), 598-620.

Miller, D. (1996). Configurations revisited. Strategic Management Journal, 17(7), 505-512.

Miller, D. (2003). An asymmetry-based view of advantage: Towards an attainable sustainability. Strategic Management Journal, 24(10), 961-976.

Mithas, S., Tafti, A., Bardhan, I., \& Mein Goh, J. (2012). Information technology and firm profitability: Mechanisms and empirical evidence. MIS Quarterly, 36(1), 205-224.

Molloy, S., \& Schwenk, C. R. (1995). The effects of information technology on strategic 
decision making. Journal of Management Studies, 32(3), 283-311.

Mueller, G. C., Mone, M. A., \& Barker Ill, V. L. (2007). Formal strategic analyses and organizational performance: Decomposing the rational model. Organization Studies, 28(6), 853-883.

Nayyar, P. R., \& Bantel, K. A. (1994). Competitive agility: A source of competitive advantage based on speed and variety. Advances in Strategic Management, 10(1), 193-222.

Nevo, S., \& Wade, M. (2010). The formation and value of IT-enabled resources: Antecedents and consequences of synergistic relationships. MIS Quarterly, 34(1), 163-183.

Nevo, S., \& Wade, M. (2011). Firm-level benefits of IT-enabled resources: A conceptual extension and an empirical assessment. Journal of Strategic Information Systems, 20(4), 403-418.

Newbert, S. L. (2007). Empirical research on the resource-based view of the firm: An assessment and suggestions for future research. Strategic Management Journal, 28(2), $121-146$

Newell, B. R., Rakow, T., Weston, N. J., \& Shanks, D. R. (2004). Search strategies in decision making: The success of "success". Journal of Behavioral Decision Making, $17(2), 117-137$.

Nolan, R., \& McFarlan, F. W. (2005). Information technology and the board of directors. Harvard Business Review, 83(10), 96-106.

Pavlou, P. A., \& El Sawy, O. A. (2006). From IT leveraging competence to competitive advantage in turbulent environments: The case of new product development. Information Systems Research, 17(3), 198-227.

Peppard, J., \& Ward, J. (2004). Beyond strategic information systems: Towards an Is capability. The Journal of Strategic Information Systems, 13(2), 167-194.

Petter, S., Straub, D., \& Rai, A. (2007). Specifying formative constructs in information systems research. MIS Quarterly, 31(4), 623-656.

Phillips, L. W., \& Bagozzi, R. P. (1986). On measuring organizational properties of distribution channels: Methodological issues in the use of key informants. Research in Marketing, 8, 313-369.

Podsakoff, P. M., MacKenzie, S. B., Lee, J.-Y., \& Podsakoff, N. P. (2003). Common method biases in behavioral research: A critical review of the literature and recommended remedies. Journal of Applied Psychology, 88(5), 879-903.

Podsakoff, P. M., MacKenzie, S. B., \& Podsakoff, N. P. (2012). Sources of method bias in social science research and recommendations on how to control it. Annual Review of Psychology, 63(1), 539-569.

Porter, M. (1985). Competitive advantage. New York: Free Press.

Premkumar, G., Ramamurthy, K., \& Saunders, C. S. (2005). Information processing view of organizations: An exploratory examination of fit in the context of interorganizational relationships. Journal of Management Information Systems, 22(1), 257-294.

Priem, R. L., \& Butler, J. E. (2001). Is the resource-based "view" a useful perspective for strategic management research? Academy of Management Review, 26(1), 22-40.

Rajagopalan, N., Rasheed, A. M. A., \& Datta, D. K. (1993). Strategic decision processes: Critical review and future directions. Journal of Management, 19(2), 349-384.

Ransbotham, S., Kiron, D., \& Prentice, P. K. (2016). Beyond the hype: The hard work behind analytics Success. MIT Sloan Management Review, 57(3), 1-15.

Ravichandran, T., Lertwongsatien, C., \& Lertwongsatien, C. (2005). Effect of information systems resources and capabilities on firm performance: A resource-based perspective. Journal of Management Information Systems, 21(4), 237-276.

Ray, G., Barney, J. B., \& Muhanna, W. A. (2004). Capabilities, business processes, and competitive advantage: Choosing the dependent variable in empirical tests of the resource-based view. Strategic Management Journal, 25(1), 23-37.

Sambamurthy, V., Bharadwaj, A., \& Grover, V. (2003). Shaping agility through digital options: Reconceptualizing the role of information technology in contemporary firms. MIS Quarterly, 27(2), 237-263.

Scarbrough, H. (1998). Path (ological) dependency? Core competencies from an organizational perspective. British Journal of Management, 9(3), 219-232.

Schilke, O. (2014). On the contingent value of dynamic capabilities for competitive advantage: The nonlinear moderating effect of environmental dynamism. Strategic Management Journal, 35(2), 179-203.

Shepherd, N. G., \& Rudd, J. M. (2014). The influence of context on the strategic decisionmaking process: A review of the literature. International Journal of Management Reviews, 16(3), 340-364.

Shrout, P. E., \& Bolger, N. (2002). Mediation in experimental and nonexperimental studies: New procedures and recommendations. Psychological Methods, 7(4), 422-445.

Sirmon, D. G., Hitt, M. A., \& Ireland, R. D. (2007). Managing firm resources in dynamic environments to create value: Looking inside the black box. Academy of Management Review, 32(1), 273-292.

Sook-Ling, L., Ismail, M. A., \& Yee-Yen, Y. (2015). Information infrastructure capability and organisational competitive advantage. International Journal of Operations \& Production Management, 35(7), 1032-1055.

Teece, D. J. (2007). Explicating dynamic capabilities: The nature and microfoundations of (sustainable) enterprise performance. Strategic Management Journal, 28(13), 1319-1350.

Tippins, M. J., \& Sohi, R. S. (2003). IT competency and firm performance: Is organizational learning a missing link? Strategic Management Journal, 24(8), 745-761.

Tushman, M. L., \& Nadler, D. A. (1978). Information processing as an integrating concept in organizational design. Academy of Management Review, 3(3), 613-624.

van Riel, A. C. R., Semeijn, J., Hammedi, W., \& Henseler, J. (2011). Technology-based service proposal screening and decision-making effectiveness. Management Decision, 49(5), 762-783.

Verhoef, P. C., \& Lemon, K. N. (2013). Successful customer value management: Key lessons and emerging trends. European Management Journal, 31(1), 1-15.

Wade, M., \& Hulland, J. (2004). The resource-based view and information systems research: Review, extension, and suggestions for future research. MIS Quarterly, 28(1), 107-142.

Wang, E. T., Tai, J. C. F., \& Grover, V. (2013). Examining the relational benefits of improved interfirm information processing capability in buyer-supplier dyads. MIS Quarterly, 37(1), 149-173.

Wang, E. T. G. (2003). Effect of the fit between information processing requirements and capacity on organizational performance. International Journal of Information Management, 23(3), 239-247.

Wernerfelt, B. (1984). A Resource-based View of the firm. Strategic Management Journal, 5(2), 171-180.

Wetzels, M., Odekerken-Schröder, G., \& van Oppen, C. (2009). Using PLS path modeling for assessing hierarchical construct models: Guidelines and empirical illustration. MIS Quarterly, 33(1), 177-195.

Wong, C. W. Y., Lai, K.-h., Cheng, T. C. E., \& Lun, Y. H. V. (2015). The role of IT-enabled collaborative decision making in inter-organizational information integration to improve customer service performance. International Journal of Production Economics, $159,56-65$.

Woodruff, R. B. (1997). Customer value: The next source for competitive advantage. Journal of the Academy of Marketing Science, 25(2), 139-153. 